\title{
What is the quality of a city? Ways of thinking spaces that change
}

Antonella Contin, Politecnico di Milano, Italy

Valentina Galiulo, Politecnico di Milano, Italy

\begin{abstract}
Understanding the effects of a metropolis' changes in scale - the rate of growth and its speed rather than pursuing the search for optimal city size, is mandatory. The New Urban Agenda discussed performance dimensions of the contemporary city's functioning mode, knowing that place quality derives from a mutual effect with the society that uses it. However, our research focuses on how city performance dimensions can be measured to establish the values of the metropolitan form that are capable of endowing metropolitan projects with meaning. The Metropolitan Paradigm of inter-scalar connection and the Metropolitan Architecture Project Hybrid Typology are the references to measure the metropolis' performance. The Metropolitan Paradigm concerns the five city dimensions: physical, economic, energetic, social and governance. In particular, the aim of the paper is to study the physical metropolitan framework and its impact on the lives of metropolitan inhabitants, socio-economic flows and the meaning of the concept of "environment" today. The city is still analysed as a spatial phenomenon represented by data/quantities related to space. Nevertheless, the value of form plays a fundamental role within the Metropolitan Discipline at all scales, as spatial relationships within metropolitan settlements are increasingly not metric but relational. In conclusion, we study the connection between history and geography, environmental issues, the Metropolitan Structural Paradigm, and the new Public Realm heterogeneous elements to represent the metropolitan quality and living-related values that constitute the Metropolitan Democracy's opportunity.
\end{abstract}

\section{Keywords}

Metropolis, New Urban Agenda, Performance Dimensions, Place quality, Democracy

\section{Metropolitan Urbanity}

\subsection{Traces of the history and the geography of the place within a map - the ground project}

Designing a Metropolis is a social project that involves the history and the geography of a place, establishing discontinuity within the collective memory of continuous territorial relations. According to Secchi (Secchi, 1986), a metropolitan project has to originate from a ground project. Ground project means that we have to consider the definition of the characters of the ground (the environment) where the Metropolitan Architecture Project will be rooted. We can describe three metropolitan conditions. The first one draws the ground, its functions and meanings into the building: a great condenser of images, functions and relations; the second reduces the ground into a podium for the technical element devoted to fluxes; and the last one considers the ground in terms of physical extension and economic value. Instead, according to Secchi, a ground project must take care of the history and the geography of a place: traces of these have to be marked on a current map, thus determining the possibility of evaluating the changing quality of space in different eras due to the impact of new projects. 
Metropolitan ground project is a complex project (in terms of functions and geographies). It concerns the concept of the Metropolitan Identity that implies "memorable" and interactive architectural images pinned into the place (Lynch,1960). They can engrave the metropolitan geographical points/places into a Mental Map. The first indicator of the metropolitan urban space's quality is the possibility to figure out its mental map, which testifies a feeling of adequacy (Lynch, 1960).

\subsection{The environmental issue - the apparatus for big-scale structuring}

The second quality indicator of metropolitan space is the possibility to figure out, in the metropolitan mental map, a synthetic way to define a place made up of both built and natural environment.

Due to the Bigness issue (Koolhaas, 1995) - spatial extension and an unprecedented temporal acceleration rate -, a specific methodology, equipment of techniques and tools for structuring the metropolitan shape and its quality indicators' definition are needed.

Landscape at this scale is a Metropolitan Architecture and Public Space's composition material too, determining a new and vast meaning. According to Gregotti (Gregotti, 1966), the environmental issue not only concerns the most significant set of problems but somewhat different problems and values.

Consequently, the Architecture of the Metropolis must deal with the specialization of various disciplines related to the city-form issue at different scales. The Metropolitan Discipline (Contin et al. 2017) thus establishes a unique spacing methodology (Eisenman,1997), the metropolitan anthropic-geographical landscape (Gregotti, 1966), allowing its evaluation not only in terms of efficiency performance but rather of quality of living. The Metropolitan Architecture and Landscape Project are a meaningful articulation of a green and grey infrastructural system that shapes a robust metropolitan civic image (Lynch, 1960): a collective memory archive and a metropolitan multiplicity of spatial identity that is local but also global. In that perspective, and according to the sustainability principles, we must root the metropolitan space quality parameters by seeking equilibrium and potential (Lynch, 1960) among the metropolitan DNA elements (Ortiz, 2017).

\subsection{The Metropolitan feeling of adequacy as space quality indicator}

If the metropolitan space has quality, it must produce a feeling of adequacy in its inhabitants (Lynch,1960). How can this be determined? The Metropolitan City must involve the environment (geography, infrastructures, and landscapes) as the project's operative element. It must aim at producing a shared and robust image of public space (by also using ICT) that should meet the needs of the inhabitants related to their cultural and economic activities. It determines the need for continuous dialogue with public politics and policies, through new instruments and knowledge tools, about their vision regarding the metropolitan identity and inhabitants' quality of dwelling. It takes into account the five elements of project sustainability (water, energy, networks, pollution and welfare). Following a nature/water-based approach, the metropolitan project explores the generative potential of the landscape, and the green infrastructures as new contents for Metropolitan Maps and Scenes (new uses, economies, and public spaces needed). The eco armatures are not only the background of the Metropolis anymore, but agents of the metropolitan space and its quality evaluation indicators.

Hence, the Metropolis deals with the long-term period. It means shifting the goal from sustainability to durability. It is the theme of urban quality and value associated with metropolitan dynamics. One of the metropolitan dynamics is the shift from a concept of public space to the proposal of a public realm that identifies the space of the contemporary metropolis. F. Choay (Choay, 2004) described the history of a city as spatial mutations of urban spaces: historically, different scales of urban spaces coexisted within a city. However, the leap in scale resulting from the revolution of the contemporary city's dimension, defined as 
bigness by Koolhaas (Koolhaas,1995), with its significant infrastructural junctures, diminished the local scale but also depreciated the traditional city's aesthetic and cultural values. Nowadays, Metropolitan Architecture is no longer related to single objects but to new urban morphotypes.

In the traditional city, consolidated public spaces and monuments played the role of cultural and social references. However, in the Metropolis, the meaning of public space and monument is no longer primarily bound to distinctive architecture. Alternatively, we talk about a monumental metropolitan approach in the public realm, where Architecture has a strategic value to form relations with the other metropolitan dimensions that together build the structure of the metropolitan territory.

Metropolitan Architecture Project's monumental approach sets the scene to build a shared robust public mental image of the city. It assures the well-being and psychological security of both inhabitants and urban users (feeling of adequacy) by establishing a new cultural and social reference at the metropolitan scale for several inhabitants' cultural identity.

We can link Lynch's concept of feeling of adequacy with Choay's idea of urbanity. The feeling of adequacy is the product of governance that makes it free (freedom/legitimation) to represent itself legitimately in public places. Facing the need to find a new way of leaving a mark in the contemporary metropolitan fabric, yet avoiding the reproduction of iconic objects, the innovation of the Metropolitan public realm is in the ground involvement into the building of a place. It presents some characteristics of the Mega-form described by Frampton (Frampton,1999): a form capable of inflecting the existing urban landscape as found because of its stable topographical feature that is eventually insinuated back into the surrounding environment. Finally, the new public realm relates to the Metropolis, achieves particular aesthetics, and defines a new sign for both the local and the metropolitan scale.

The long-term project (permanence of the durability of metropolitan elements' relations) of the Metropolis means: maintaining, developing and transforming the connections with other elements that define the metropolitan dimension. The dynamic relations that change over time make the project permanent in the metropolitan structure. Unlike the static monumental value of the past, the new public realm has an urban quality that deals with the complexity of modern functions linked to metropolitan dynamics. It is intimately related to the issue of the identity of the local scale and its significance conveyed by the great architectural image at the metropolitan scale.

\subsection{The need for a Metropolitan structure paradigm}

At the metropolitan scale, reaching the feeling of adequacy indicates a renewed relationship among metropolitan spaces defining the formal spatial quality and its new measures. The system of proportional measures related to both the dimension of territorial sustainability and the metropolis' speed-time (Venturi, Izenour, Scott Brown, 1977) is allowed by the metropolitan structural paradigm: the Metro-Matrix (Ortiz,2014). The Metro-Matrix Approach allows resilient articulation of the interface between city, agriculture and nature by promoting the quality of dwelling and by ensuring human well-being within the Metropolis. It holds together the past city context with the new city contexts and measures, which represent the metropolitan dynamics defining new locations and boundaries within the Metropolitan Architecture Projects Acupuncture Chart. The intensity of the metropolitan time is then fixed in the concrete Metropolitan Architecture Project, which is an open project with enduring values.

\subsection{Metropolitan Democracy: the goal}

The lack of a more symbolic than physical relationship with the place does not allow to determine the phenomenon that Choay (Choay, 1972) called "building competence" or "building monuments competence", whose power concerns allowing men to act in urban space by qualifying their time through 
intersomaticity. The decadence of that competence determines the loss of effectiveness of residents' actions in space: knowing how to inhabit a space and the practices it consents, in order to build it without diminishing the possibility of finding space for social gatherings, a job, and leisure time activities, namely quality of life.

Today, Metropolitan urbanity is the relationship between human time and the inhuman time of technology, the tyranny of the Smart-city. Democracy is, instead, a humanistic fact. The time that prevails today is brutal; it is the time of numbers. The criticism levelled at the contemporary urban model passes through the ability to discover unnamed (not-conceptualized) areas inside the metropolitan city model, which can have a metropolitan quality through a critical analysis of the traditional terminology: city, urbanity, urban and urbanization. This first approach reveals that the indissoluble relationship between urbs (space) and civitas (community) no longer exists and that, perhaps, not even the two terms (urbs and civitas) still exist. Choay's analysis (Choay,2004) reminded us that, in the city of Paris, the urban space constituted the framework for three types of communication related to material goods, information and feelings (conviviality). The latter space is concretized by the Alphand's parks, where the unconscious city was nested thinking about Aragon's surreal descriptions (Aragon,1926). The Parisian park system was the way to determine the feeling of adequacy through the multiscale approach dealing with the green-grey infrastructure project. It goes from the great Bois de Boulogne to the Buttes-Chaumont, to the district square through the boulevards.

Currently, we can deduce that the term urbanity means behavioural order, and that it is a space to determine the communication that can pass through bodily sensitivity. Nowadays urbanity is related to the whole metropolitan fabric (metropolitan spatial dimension) and to conviviality (domesticity), which arises from environmental knowledge and the several identities that determine the place's singularity. Subsequently, it stimulates the inhabitants' feeling of belonging and beauty awareness. Today, the conditions of environmental value are the basis for a sustainable project that can guarantee the quality of life, which corresponds to the values today's society considers worthy of lasting. It is a quality that must be accessible to all. That is Democracy.

Hence, urbanity/conviviality is quality based on the possibility of living in the city connected to other spaces plus the city dwellers' relationship quality; namely, the link between spaces (accessibility) and the possibility of exchanging feelings. Today, in a consumerist society, conviviality is the cosmopolitan attitude associated with self-representation (Reeve, Simmonds, 2000): ubiquity and information exchange without affection. Metropolitan Architecture at the local scale must then determine the spatial condition for the development of affection exchange. The spatial structure thus acquires a new symbolic coordinate system, which allows "bright and sensuous" images and information (Lynch, 1960) to penetrate into the bloodstream. Memorable images and information (for a mental map), referring to a scale change.

\section{Metropolitan Architecture Typologies as a driver of city quality}

\subsection{The cultural leap}

The relational approach is a product of the contemporary paradigm cultural leap. The contemporary city is understood as a Net-City, meaning a Tele-City, using the definition proposed by G. Shane (Shane, 2005). 
The prefix "tele" etymologically refers to the idea of distance, wanting to emphasize the association of the contemporary urban scenario with a dispersed physical reality, compared to an amorphous agglomeration, which forms the so-called urban archipelago. The idea of territory as an extreme urban form derives from the opening of the city. Hence, the territory is multiscale, involving the use of several dimensions in the same project. The task of the Metropolitan Architecture Project is 'How to give value to new qualities of this hybrid territory'.

The new scale of metropolitan urbanity, given by the size of the infrastructural network, causes a change in the rationale of structuring settlements: the historical city loses power because the Metropolis no longer requires a physical centre where it can settle and represent itself (Gregotti, 1993). The goal is to determine new relationships between new and old epicentres. In the Postmetropolis (Soja,2000), the relationship with history settles in the de-structuring of the changed contemporary city, in which it is no longer possible to clearly distinguish between centre and periphery. The designer horizon lies on the awareness that the project is capable of delineating thresholds of an urbanity that is in the process of being realized. In this sense, the metropolitan urban project is not the rewriting of an interrupted text, but the creation of new geography to understand, find and make the Metropolitan city's quality.

\subsection{The New Built Form types or new land uses as enablers of qualified metropolitan}

\section{dwelling}

The Metropolitan Paradigm allows to place centralities qualified by Characteristic Figures. It is a way to make the new centralities attractive for the different agents of the city. Metropolitan Architecture Project, Heterotopias (Shane, 2005) or Mega Forms (Frampton, 1999) are hybrid architectural entities articulating scales (Fenton, 1985) or urban-morphotypes (d'Alfonso, Samsa,2001), thus determining original configurations of new built form types (Reeve, Simmonds, 2000). They are the foundation of mental maps at the metropolitan scale, the formation of a "body-space" (Shane, 2005) as the metropolitan fabric emerges. According to Rowe's reversal code (Rowe, Koetter, 1984), open space is reversed from background to figure involved in the construction of a mental map, starting from the new character and conceptualization of the void or "body-space" or "space in between" at the metropolitan scale. The formal paradigm of "space in between", structured by eco-armatures (Goveurneur, 2016), allows to recognise a conventional open space form, and provides the potential for a system of gradation of public, semi-public, common and private spaces within a functional rationale. The Metropolitan Architecture Project - a function of creative and managerial moments - shapes that void as a gradient of formality. Finally, the Metropolis is still analyzed as a spatial phenomenon, being represented by data/quantities that are related to space. However, the value of form plays a fundamental role within the Metropolitan Discipline at all scales, as spatial relationships within metropolitan settlements are increasingly not metric but relational.

\subsection{The First Hybrid}

The importance of hybrid architecture typology emerges in a society where the city becomes a system at the service of the infinite choices and needs of urban actors (Shane, 2005). They deal with different processes and indicators of results based on which to evaluate the quality of metropolitan urbanity, precisely hybrid metropolitan typology capable of influencing the functioning process of the metropolitan urban model into which it fits from the human scale to the territorial and even global scale. We call it an urban morphotype indicating that something typical of the city is part of the current typology.

Metropolitan residents can convey multiple choices in a quick time, so, they need a place capable of promoting flexibility and transformability of the city. That is the natural task of hybrid buildings. The 
typology of the hybrid building expresses all the potential that the hybrid has in informing the Net-City about an alternative development model, which is more suited to the needs of urban actors.

D. Grahame Shane's analysis, starting from the reworking of Lynch's three theoretical models of the city, prefigures an urban system that evolves from the recombination of its three fundamental elements: the enclave, the armour and heterotopia. The third concept, in particular, associated with different architectural typologies, introduces the hybrid building typology, which we shall define as the symbol of the contemporary city model, the Net-City paradigm.

The characteristics of the hybrid building (Fenton, 1985) are linked to the concept of heterotopia, defining a point of mediation between two entities, reinterpreting the hybrid as a recombinant architecture. This analysis will be crucial to create a conceptual bridge that can demonstrate its dominance in terms of quality of living over the rest of the urban fabric in the current model of the generic city (Koolhass, 2006).

The term 'recombinant' comes from the panorama of studies of the compositional structure of DNA carried out by Francis Crick and James Watson (Shane, 2005). It is associated with architecture starting with the work of D. Grahame Shane, called 'Recombinant Urbanism', to define the possible presence of an urban structure, a DNA of the metropolitan city capable of transforming, altering and reshuffling itself in order to achieve characteristics that differ from its original state. Since recombination is considered a process of 'crossbreeding and independent assortment of new combinations of genes that do not appear in the parents', it allows change and response to altered circumstances, thus explaining the 'mutations' from generation to generation and the path of Darwinian natural selection.

Similarly, we can find this evolutionary pattern within urban change. The search for greater efficiency, profit or pleasure drives city users to 'splice' urban structures that manage flows. They use the elements that make up the city, stratifying one on top of the other, modifying elements' functioning mode and relationships, thus producing new scenarios for their activities and reusing existing ones for new circumstances. 'Urban splicing' (Shane, 2005), similarly to genetic recombination, includes cataloguing, layering, overlapping and recombining disparate elements in order to create new combinations reaching the quality of dwelling.

The word 'hybridization' is a term that has been lent to architecture by the scientific realm. The meaning of this term, coined in its meaning by Mendel and Kolreuter (Bateson, 1913), describes the 'process of systematically combining different species in order to obtain a different species from the original one'. This study led to the creation of the term hybrid vigour or heterosis, and later, also to the opposite term, 'hybrid sterility', defined as the inability of the result of hybridization to reproduce.

This scientific approach can be linked to the Metropolitan Architecture Project. Over the years, the combination of different programmes within a single building has led to several examples, some of which have survived, while others have decayed. However, not all buildings that combine different functions inside can be defined as Hybrid Architecture. As claimed by Fenton (Fenton,1985), the first examples of hybrid architecture were identified in the 19th century in the United States, particularly in New York.

In the latter half of the 20th century and the advent of the 21st, experimentation on traditional typologies pushed once again in the direction of greater fluidity and integration of various programmes, defined by the increasing range of residents' needs, within large heterotopic hybrid nodes. A new period of strong aspiration for innovation and change initiated the rebirth of hybrid buildings, defined as an architecture of change. This new architectural typology fits perfectly into today's Net-City thanks to its recombinant capacity and its flexibility to re-code several urban agent's needs in liveable spaces. 


\subsection{From the mixed-use tower to the cyber-hybrid mega-form: new strategies for the}

\section{Metropolitan Architecture Project}

With the advent of new communication technologies and the incredible diversification of the architectural scenario, we can see how Fenton's definition of hybrid buildings urgently needs to be updated. Unifying different uses within a single structure is no longer a point of arrival to achieve architectural and city quality in the sense that it is capable of responding to the needs of the contemporary city but is only a starting point.

What Fenton describes in his analysis is how a series of functions can be united within a building, and the consequent hybrid form is the logical outcome of this transformation process. However, today a hybrid building is hugely more complex in its functioning mode and internal dynamics, far beyond the functions it contains.

The recent development of new frontiers in hybrid architecture has allowed us to explore new formal solutions, dissociating ourselves from the idea that the grid should dominate the building. We can say that, because of its heterotopic nature, hybrid is a project in which the stasis component (enclave) and the movement component (armature) interact with each other, both inside the building and with the rest of the context.

In order to define metropolitan quality space, the hybrid building must be located in a specific context, where a ground project strategy can be defined as the fundamental declaration of grounding the generic city process. To achieve this purpose, the three-dimensional local matrix must be recombinant and should be able to stabilize (or destabilize) the surrounding urban dynamics on different levels. The new metropolitan Hybrid building, located following the Metro-Matrix Metropolitan Acupuncture Chart's indication, could become the ordering agent of the enclave armour, at the metropolitan region scale.

\subsection{The new hybrid season of the metropolitan city as a driver of space quality}

Considering the new Hybrid building an innovative typology at the metropolitan scale means having control of the relationship between interior and exterior and, therefore, between public, private and common space. The physical boundaries of the heterotopic enclave are no longer defined by the walls of the architectural object itself but are permeable. They are able to guarantee access to different urban actors with different roles, including the city that the hybrid itself reflects ( $A+T$ Research Group, 2020). According to our research, it might be possible to detect categories that could help planners to evaluate the metropolitan morpho-type space quality:

Reflexivity: the hybrid building seeks to have an impact on both the observer and the urban actor. It is proposed as a landmark within the metropolitan scenario.

Sociability: the hybrid building, with its complexity, compresses the public and private spheres within it, exploiting both in order to get the most out of its use for all urban actors, and accommodating the different lifestyles that represent metropolitan life in the Net-City.

Formality: the hybrid building is not the result of functional isolation spaces in the city.

Processualism: the hybrid building should be linked to the sequence of processes of composition and management of space over time, interpolating the need of the public and private body. Therefore, the establishment of a strategic action design programme is a priority action in order to achieve the combination of different functions within a unique building to ensure a strong interconnection of activities, which are changeable in time. 
Inter-scalarity: the hybrid building is properly linked to the designer's ability to be able to represent, in a unique project, the quality of the space at a different scale. To reach this purpose, the strategy section becomes the fundamental tool to understand the value of space, time, functions and common habitus of local agents.

Density: the complex conditions of urban density are factors that determine the development of hybrid buildings, as they enhance the ability to rework weaknesses at different scales of the context and revitalize entire enclaves.

Inter-somaticity: of space, considering hybrid building projects as intermediary devices between architecture and urban planning. In the metropolitan city, it can play a fundamental role in the process of transition from a city composed of parts to an integrated, interconnected system. Hybrid architecture fosters the place identity since it is the physical manifestation of a network of relationships between urban actors.

Measurability: it is a category to identify the measure of scale relationships between the dense urban fabric and common and public space.

Recombinability: it can be based on its functioning process and on the relationships and dynamics it activates. Evaluations closely linked to the architectural composition field become obsolete because it no longer represents the dynamism and variability of these buildings.

It is mandatory to pursue the objective of the metropolitan space's quality to define a design methodology capable of fostering the transition from an urban system where heterotopia of illusion - or rather, the hybrid building - is still considered an exception to the rule, to a system where interconnectivity and dynamism of this typology are no longer limited to being defined as an experimentation with a high risk of failure. The Hybrid Building is a real, viable and scalable option for the organic and efficient development of the urban metabolism of the Net-City in order to bring out a quality that is now neglected.

\section{The final note}

The term metropolis implies a geographical area dimension that is greater than that of historical cities (in Italy it is much greater than municipal boundaries). Hence, the link between geography and history must be given due consideration (Febvre, 1922) in the perspective of an urban biography. The semi-independent processes of undifferentiated growth, the hyper-planned processes of the immaterial and transport networks, as well as the centralities at the inter-networks, qualify the urban biography already involving the metropolitan dimension. This is why our idea of metabolism and its three operations - maintain, develop and transform - should be at the centre of metropolitan management. We cannot imagine how it could be missing. Finally, because the City of Muses or the city of art is our research's brand (its driving core), we encourage training in Anthropology of the inhabited metropolitan city. First of all, the City of Muses concept was created concerning imagines agentes (Yates, 1997). Then, about those images that, as Rossi intended, descend to archetypes while repeating them as analogues in the urban biography of the present day city. Secondly, because we no longer look only at the building type but rather at interpretative maps based on topographical/geographical elements and their relationships. From a hermeneutic perspective, we want to detect possibilities and local resources, both human and natural, towards their "liberation" from the traditional urban accumulation processes, using a Marxist terminology. This is the reason for the word "Muse", the value of the hermeneutic approach that discovers/invents the urban facts not for narcissistic exhibition, nor for financial interest, but for what we call the "public", which includes natives and residents among others.

Figure 1. Parma City of Muses, Landsound Plan. Source: MSLab within Michele Moreno. 
Hence, the case study. Parma City of Muses (fig.1) is a masterful example, since it is the production of the map of the remarkable places of Parma invested by a series of events with the relative scenography. We conceived events involving many arts and, especially, music, as well as, through the introduction of modern technical devices as art objects "revisited" mythically or poetically. Through a "story", such devices acted by creating a new spatial-temporal interweave between geography, artefacts, and artistic events. In short, it is a real map invested with ideal meanings, and is highly evocative of the mission of the metropolis' managers, not as bureaucrats but as curators of a delicate public asset. Nevertheless, we defined an analogous map, more complex than the one of Aldo Rossi's analogous city - more intimate compared to the epic one that new devices have created here.

What is more, the map is not drawn but interacts with the residents of Parma, who can thus jointly test the quality of a city within its territory.

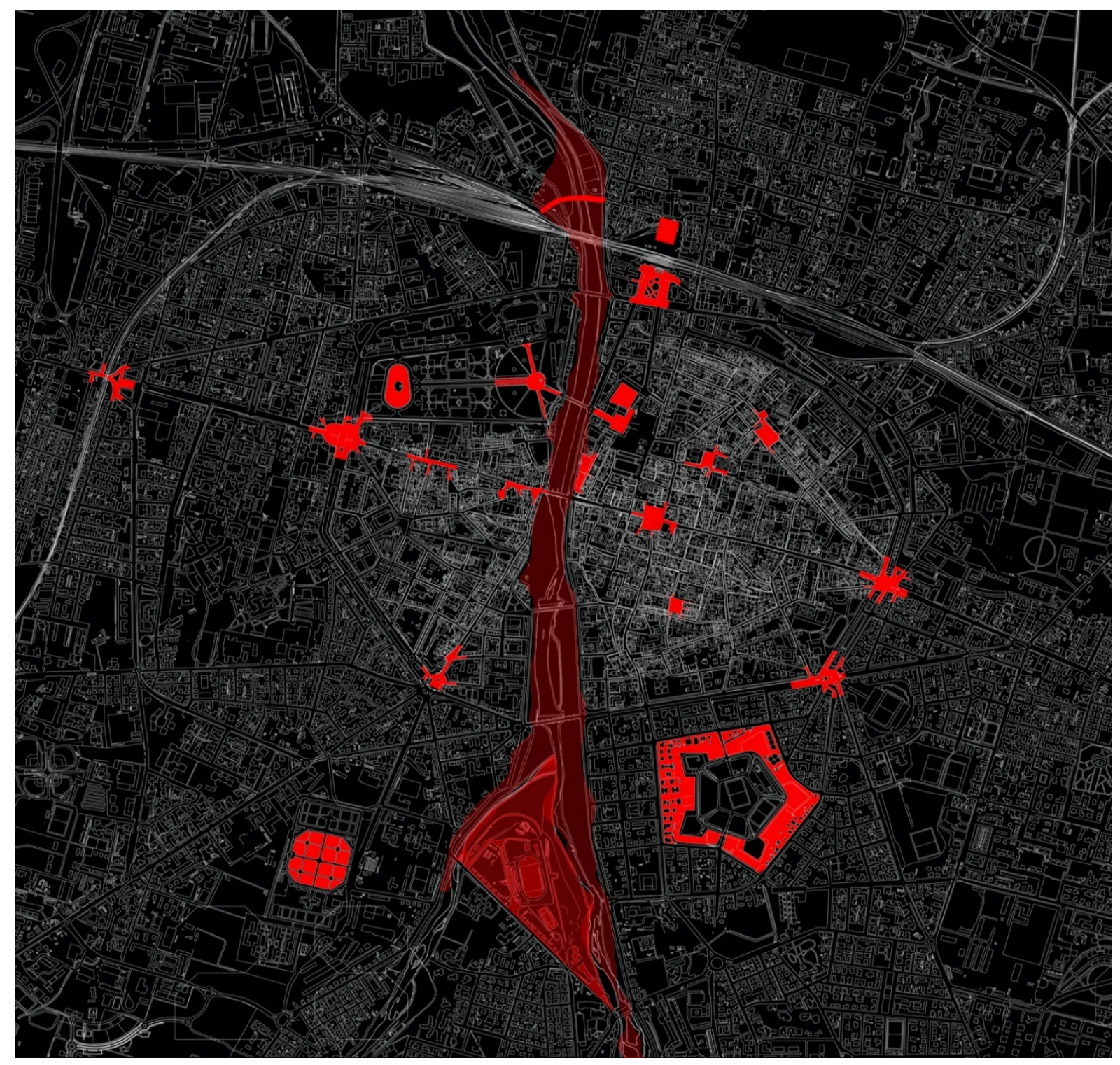




\section{References}

Arpa, J., Mozas, J., Per, A. F. (2014). This is Hybrid. Álava: A+T Architecture Publishers

Arpa, J., Mozas, J., Per, A. F. (2020). 50 Hybrid Buildings: catalogue on the art of mixing uses. Álava: A+T Architecture Publishers

Contin, A., (2015). Questo: Metropolitan Architectur. Santarcangelo di Romagna: Maggioli Editore d'Alfonso, E., Samsa, D. (2001). Architettura. Milano: Mondadori

Aragon, L. (1926). II paesano di Parigi. Milano: II Saggiatore

Bateson, W. (1913). Mendel's Principles of Heredity. Cambridge: Cambridge University Press.

Choay, F. (2004). Espacements. Figure di spazi urbani nel tempo. Milano: Skira Edizioni

Choay, F. (1972). L'allégorie du patrimoine. Paris: Seuil

Eisenman, P. (1997). Peter Eisenman 1990-1997 In El croquis 83. 1-176

Febvre, L. (1922). La terra e l'evoluzione umana. Introduzione geografica alla storia. Torino: Einaudi Fenton, J. (1985). Hybrid Buildings in Pamphlet Architecture 11. Princeton: Princeton Architectural Pr Frampton, K. (eds). (1999). Megaform as Urban Landscape. 1999 Raoul Wallenberg Lecture. Ann Arbor: Univ of Michigan

Giddens, A. (1991). Modernity and Self-Identity: Self and Society in the Late Modern Age. Cambridge: Polity Press

Gregotti, V. (1966). Il Territorio dell'Architettura. Milano: Feltrinelli

Gregotti,V. (1993). La città visibile: Frammenti di disegno della città ordinati e catalogati secondo i principî dell'architettura della modificazione contestuale. Torino: Piccola biblioteca Einaudi

Gouverneur, D. (2016). Diseño de nuevos asentamientos informales. Bogotà: Universidad de LaSalle Koolhaas, R. (1995). Bigness, or the Problem of Large. S, M, L, XL. New York: The Monacelli Press Lynch, K. (1960). The image of the city. Cambridge Massachusetts: MIT Press

Mastrigli, G. (eds). (2006). Junkspace. Per un ripensamento radicale dello spazio urbano. Ed. Italiana. Macerata: Quodlibet.

Ortiz, B.P. (1997). Metropolitan Discipline. Inception Lecture series 02/20. Lecture recording at https://youtu.be/otjvZ-2qFfk. Delivered 3 August 2017

Reeve, A., Simmonds, R. (2000). Hyperreality in the shire: Bicester Village and the village of Bicester in URBAN DESIGN International 5. 141-154. Oxford: Joint Centre for Urban Design, Oxford Brookes University Rowe, C. Koetter, F. ( 1984). Collage city. Cambridge Massachusetts: MIT Press

Santamaria, G. (eds). (2007). New York-Milano: disegno della città per la regione urbana. Firenze: Alinea Secchi, B. (1986). Progetto di suolo in CASABELLA. 520/52. 19-23.

Shane, G. D. (2005). Recombinant urbanism. Conceptual Modeling in Architecture, Urban Design, and City Theory. West Sussex: Wiley-Academy

Soja, E. W. (2000). Postmetropolis: critical studies of cities and regions. Los Angeles: Blackwell Publishing 
Venturi, R., Izenour, S., Scott Brown, D. (1977). Learning From Las Vegas, Cambridge Massachusetts: MIT Press

Yates, F. (1997). L'arte della memoria. Torino: Einaudi

\section{Acknowledgement}

Florenzano,D., Ibrido 2.0: Ia necessità di un'Architettura Ricombinante. Analisi critica dell'opera di Shane e Fenton sulla tipologia dell'edificio ibrido e sul suo rapporto con la Net City, Bachelor Thesis A.A.2019/20 Politecnico di Milano, School of Architecture Urban Planning Construction Engineering. 